\title{
Tectonic boundaries, crustal weakness zones and plume-subcontinental lithospheric mantle interactions in the Serra do Mar dyke swarm, SE Brazil
}

\author{
Sergio de Castro Valente ${ }^{1}$, Artur Corval ${ }^{2}$, Beatriz Paschoal Duarte , Robert M. Ellam $^{4}$, Anthony \\ E. Fallick, Ian Gordon Meighan ${ }^{6}$ \& Thiago Dutra ${ }^{7}$
}

\begin{abstract}
Tholeiitic basalts of Early Cretaceous age (ca.132 Ma) integrate the Serra do Mar Dyke Swarm in Southeastern Brazil. The dolerites are included in a transitional tholeiitic series that can be divided in a low$\mathrm{TiO}_{2}$ and high- $\mathrm{TiO}_{2}$ suites on a geochemical basis. Parental compositions have $\mathrm{La} / \mathrm{Yb}_{N}$ and $\mathrm{La} / \mathrm{Nb} b_{N}>1$ pointing to a predominantly contribution from the subcontinental lithospheric mantle in the generation of the two suites. However, the occurrence of a high- $\mathrm{TiO}_{2}$ dolerite in the swarm with $\mathrm{La} / \mathrm{Nb}_{\mathrm{N}}=0.3$ and $\mathrm{La} / \mathrm{Yb}_{\mathrm{N}}=9.9$ ratios can indicate a contribution of a fertile sublithospheric mantle in the generation of the Serra do Mar Dyke Swarm likely to be represented by the Tristan da Cunha plume. This paper proposes that the Tristan da Cunha plume may have melted locally in places where the Gondwanaland lithosphere had undergone greater thinning due to the reactivation of crustal weakness zones nearby major terrane boundaries amalgamated in Proterozoic times resulting in the generation of restricted volumes of plume-derived tholeiitic basalts.
\end{abstract}

Keywords: Tholeiitic basalts, subcontinental lithospheric mantle, Tristan da Cunha plume and dykes.

\begin{abstract}
Resumo Limites tectônicos, zonas de fraqueza crustal e interações entre pluma e manto litosférico subcontinental no Enxame de Diques da Serra do Mar, SE do Brasil. Basaltos toleíticos do Cretáceo Inferior (ca.132Ma) integram o Enxame de Diques da Serra do Mar no Sudeste do Brasil. Estes basaltos incluem-se numa série transicional de afinidade tholeiitica com duas suítes: baixo- $\mathrm{TiO}_{2}$ e alto-TiO . Líquidos parentais da suíte de baixo- $\mathrm{TiO}_{2}$ e alto- $\mathrm{TiO}_{2}$ apresentam razões $\mathrm{La} / \mathrm{Yb}_{(\mathrm{N})}$ e $\mathrm{La} / \mathrm{Nb}_{(\mathrm{N})}>1$. Estes dados sugerem pelo menos uma contribuição do manto litosférico subcontinental na geração dos basaltos de ambas as suítes. A ocorrência de um dique de basalto no enxame com $\mathrm{La} / \mathrm{Nb}_{\mathrm{N}}=0.3$ and $\mathrm{La} / \mathrm{Yb}_{\mathrm{N}}=9.9$ pode sugerir a contribuição de um componente mantélico sublitosférico fértil na geração do Enxame de Diques da Serra do Mar, possivelmente representado pela pluma de Tristão da Cunha. Este trabalho propõe um modelo geodinâmico em que a pluma pode ter fundido em locais onde a litosfera do Gondwana foi submetida a maior afinamento devido à reativação de zonas de fraqueza crustais, e consequente transferência de stress ao manto subjacente, próximo aos principais limites tectônicos associados à amalgamação daquele supercontinente no Neoproterozóico, resultando na geração de pequenos volumes de basaltos tholeiiticos com assinatura sublitosférica fértil.
\end{abstract}

Palavras-Chave: Basaltos tholeiiticos, manto litosférico subcontinental, pluma de Tristão da Cunha e diques.

INTRODUCTION The geochemical provinciality is one of the most relevant aspects concerning the continental basalt provinces. Such provinciality has been attributed by many authors to either distinctive partial melting degrees of a single mantle source or derivation from different mantle sources (e.g., Fodor et al., 1985; Gibson et al., 1995; Marques et al., 1999, 2003).

Dykes of Early Cretaceous age (148-132 Ma; whole-rock and plagioclase Ar-Ar and K-Ar data; Turner et al., 1994; Guedes et al., 2005) intrude gneisses and granitoids of the Upper Proterozoic-Silurian, Ribeira Orogen (Heilbron et al., 2000; Schmitt et al., 2004) comprising the so-called Serra do Mar Dyke Swarm
(Valente et al., 1998a) along Southeastern Brazil.

In this paper we present simple geodynamic scenarios for the Gondwanaland breakup based on geochemical data (Valente, 1997; Corval, 2005) obtained for the high- $\mathrm{TiO}_{2}$ tholeiitic suites within the central portion of the Serra do Mar Dyke Swarm.

\section{GEOLOGICAL AND GEODYNAMIC SET-} TINGS The main events related to the South American Platform reactivation (Almeida et al., 1976) include widespread tholeiitic basalt magmatism and the formation of rift basins along the Brazilian continental margin (Chang et al., 1992; Milani and Thomaz Filho,

1 - Department of Geosciences, UFRuralRJ. Seropédica, RJ. E-mail: sergio@ufrrj.br

2 - Faculty of Geology, UERJ, Maracanã - Rio de Janeiro - RJ. E-mail: artur.corval@gmail.com

3 - Faculty of Geology, UERJ, Maracanã - Rio de Janeiro, RJ. E-mail: biapasch@uerj.br

4 - Scottish Universities Research and Environmental Centre, East Kilbride, Scotland, UK. E-mail: R.Ellam@suerc.gla.ac.uk

5 - Scottish Universities Research and Environmental Centre, East Kilbride Scotland, UK. E-mail: T.Fallick@suerc.gla.ac.uk

6 - The Queen's University of Belfast, Belfast, UK. E-mail: meighani@tcd.ie

7 - Faculty of Geology, UERJ. Maracanã - Rio de Janeiro - RJ. E-mail: geologothiago@yahoo.com.br 
2000; Misuzaki and Thomaz Filho, 2004). These events are related to the rifting of the West Gondwanaland which started in Early Cretaceous times (ca. 137 Ma; Ar-Ar, whole-rock and plagioclase, Turner et al., 1994) or even earlier ( $c a .193 \mathrm{Ma}$; K-Ar, whole-rock, Guedes et al., 2005). Such magmatism is mostly represented by extrusion of basaltic flows in both Palaezoic (Paraná; e.g., Piccirillo and Melfi, 1988; Peate, 1997) and Mesozoic basins (Pelotas, Santos, Campos and Espírito Santo; e.g., Fodor et al, 1983/84; Fodor and Vetter, 1984; Misuzaki et al.,1992; Caineli and Mohriak, 1999; Thomaz Filho et al., 2000; Mohriak et al., 2002). Coeval dyke swarms, namely the Serra do Mar Dyke Swarm (e.g. Comin-Chiaramonti et al., 1983; Regelous, 1993; Garda, 1995, Valente et al., 1998a,b; 1999a,b; Guedes et al., 1999; Lobo et al., 1999), the Ponta Grossa (and East Paraguay) Dyke Swarm (e.g., Piccirillo et $a l ., 1990)$ and the Florianópolis Dyke Swarm (Raposo et al., 1998) occur associated with those basaltic flows (Fig. 1).

In general, the Mesozoic rift basins and the tholeiitic magmatism have been taken as resulting from the rotation of the south portion of the South America plate with the development of internal deformation which is indicated by the extension in the NE-SW direction observed in the Ponta Grossa and the East of Paraguay dyke swarms (Turner et al., 1994). Regardless the cause-effect relationships between plume impact and rifting, the basaltic magmatism seems to be related to lithospheric extension (Chang et al., 1992; Cainelli and Mohriak, 1999) and the presence of a regional thermal anomaly usually associated with the Tristan da Cunha plume (Gibson et al., 1995; Valente, 1997; Mohriak et al., 2002).

THE SERRA DO MAR DYKE SWARM The Serra do Mar Dyke Swarm was emplaced in the central segment of the Upper Proterozoic/Silurian, Brasiliano/ Pan-African-related Ribeira orogen in SE Brazil (Fig. 2). The dyke swarm comprises an Early Cretaceous tholeiitic basalt series with hundreds of regular, long, tens of metres-thick, vertical, predominantly ENEtrending dolerites with remarkably uniform textures and structures (Valente, 1997), although NNW-trending dolerites occur locally in the northwest portion of the dyke swarm (Guedes et al., 2005).

The Serra do Mar dykes are relatively evolved (MgO 4-11 wt.\%; Mg\# 38-71), transitional, mostly quartz- and hypersthene-normative basalts that can be grouped in a predominantly high- $\mathrm{TiO}_{2}$ suite and a subordinately low- $\mathrm{TiO}_{2}$ suite unrelated by any evolutionary process (Valente, 1997; Tetzner et al., 2001; Corval, 2005). The occurence of high- and low$\mathrm{TiO}_{2}$ suites imprints a geochemical provinciality in the dyke swarm similar to that observed in the ParanáEtendeka province (e.g., Piccirillo and Melfi, 1988; Peate, 1997).

Two main low- $\mathrm{TiO}_{2}$ suites have been discriminated in the Serra do Mar Dyke Swarm on a geochemical basis (Monteiro and Valente, 2003), namely the Búzios (e.g. $\left.\mathrm{La} / \mathrm{Yb}_{(\mathrm{N})}>5\right)$ and the Serrana $\left(\right.$ e.g. $\left.\mathrm{La} / \mathrm{Yb}_{\mathrm{N})}<5\right)$ suites. Proposed petrogenetic models for the Búzios basalts pointed out that they evolved by AFC (Assimilation and Fractional Crystallisation) without changing of the fractionating assemblage whilst the Serrana basalts seem to have evolved solely by fractional cristallisation with changing of the fractionating assemblage (Monteiro and Valente, 2003). Both low- $\mathrm{TiO}_{2}$ suites have $\mathrm{La} / \mathrm{Yb}_{(\mathrm{N})}$ and $\mathrm{La} / \mathrm{Nb}_{(\mathrm{N})}$ ratios higher than unity indicating at least a contribution from the subcontinental litospheric mantle in the generation of these basalts (Corval, 2005).

Three high- $\mathrm{TiO}_{2}$ suites have been discriminated in the Serra do Mar Dyke Swarm on the basis of their distinctive $\mathrm{La} / \mathrm{Yb}$ ratios as well as partial melting modelling, althought one of them largely predominates in the swarm (Corval, 2005). This predominatly high$\mathrm{TiO}_{2}$ suite in the Serra do Mar Dyke Swarm closely resembles the Urubici basalts of the Paraná-Etendeka province (Peate et al., 1992) and evolved by AFC without changing of the fractionating assemblage. Parental compositions in this suite have $\mathrm{La} / \mathrm{Yb}(14.2)$ and $\mathrm{La} / \mathrm{Nb}$ (1.8) ratios that indicate at least a contribution from enriched mantle sources (Corval, 2005). Table 1 presents average $\mathrm{Ti} / \mathrm{Y}, \mathrm{La} / \mathrm{Yb}$ and $\mathrm{La} / \mathrm{Nb}$ ratios of the main lo and high- $\mathrm{TiO}_{2}$ suites of the Serra do Mar Dyke Swarm.

\section{PETROGENETIC MODELS FOR THE HIGH-} TIO BASALTS: EVIDENCE FOR THE INVOLVEMENT OF LITHOSPHERIC AND SUBLITHOSPHERIC, PLUME-LIKE MANTLE COMPONENTS Lithogeochemical data obtained by the authors of this paper in previous works (Valente, 1997; Corval, 2005; Dutra, 2006) have been used to constrain preliminary petrogenetic and geodynamic models (e.g. Valente et al., 1999a). These data show that the parental composition (sample RJ-19) of the predominantly high$\mathrm{TiO}_{2}$ basaltic suite in the Serra do Mar Dyke Swarm can be associated with an enriched source (e.g. Valente et al., 1998a). Such source is likely to be represented by the subcontinental lithospheric mantle taken as a major enriched reservoir (e.g., Hawkesworth et al., 1992). This is in general agreement with models showing the non-involvement of a plume-like component and an exclusive role of the subcontinental lithospheric mantle in the genesis of continental basalts elsewhere (e.g. Paraná-Etendeka) as pointed out by some authors in recent papers (e.g., Marques and Ernesto, 2004).

We used selected isotope data obtained for the predominantly high- $\mathrm{TiO}_{2}$ basalts of the Serra do Mar Dyke Swarm (Valente, 1997) with discernable lithospheric signatures (e.g. $\mathrm{La} / \mathrm{Nb}>1$ ) to constrain Sr-Nd binary mixing models to test for the possible involvement of plume-like and lithospheric components in their petrogenesis (Fig. 3). Selected end-members used in the modelling were average compositions for the Tristan da Cunha ankaramitic basanites and basanites (LeRoex et al., 1990) as well as an average lamproite composition (Rock, 1991) likely to represent the plume-like and the subcontinental lithospheric mantle 


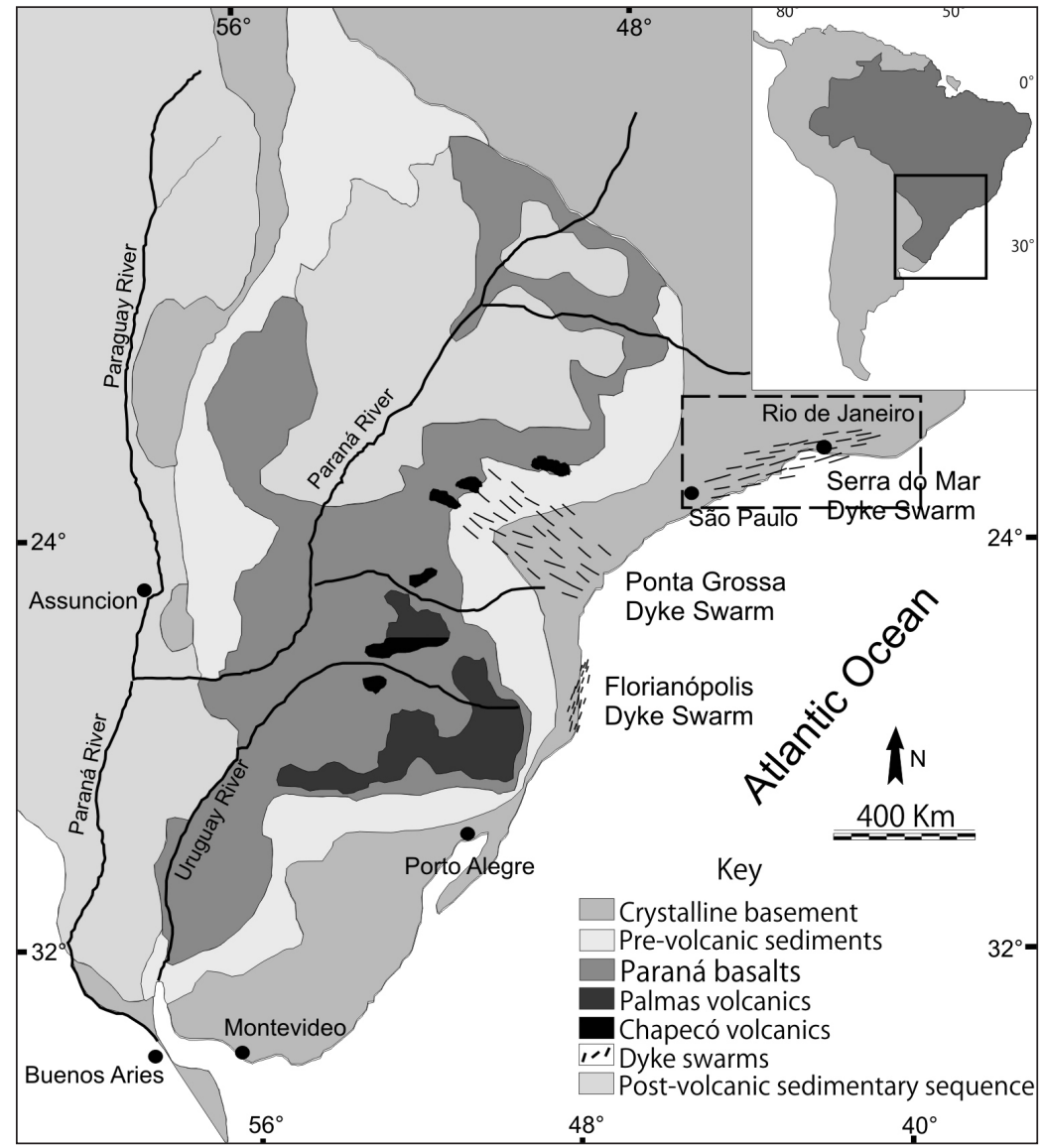

Figure 1 - Sketch map showing the main lithological units of the Paraná Continental Flood Basalt Province, the Paraná basin-related sedimentary sequence as well as the major dyke swarms in southeastern Brazil (modified from Marques \& Ernesto, 2004). The dashed line rectangle represents approximately the area shown in Figure 2. Inset: Location (square) of the area of the sketch map in South America. Inset: Location (square) of the area of the sketch map in South America. Modified from Marques \& Ernesto, 2004.

components, respectively. The results indicate that the $\mathrm{Sr}$ and $\mathrm{Nd}$ isotope compositions of sample RJ-19 taken to represent the parental liquid of this high-TiO suite plot on the mixing curve between plume-like and lithospheric components. The trend towards higher ${ }^{87} \mathrm{Sr} /{ }^{86} \mathrm{Sr}_{(132)}$ values are likely to result from crustal contamination processes (Valente, 1997)

As aforementioned, the high- $\mathrm{TiO}_{2}$ basalts of the Serra do Mar Dyke Swarm display La/Nb $>1$ ratios typically associated with lithospheric sources. As such, these samples display a $\mathrm{Nb}$ negative anomaly when plotted in chondrite-normalized multielementar diagrams (Fig. 4). For instance, sample RJ-19 represents the parental liquid of the predomilantly high$\mathrm{TiO}_{2}$ suite within the swarm (Valente, 1997) whereas sample DB-I-34 represents an evolved composition of the same suite (Corval, 2005) and both display a $\mathrm{Nb}$ negative anomaly. As a noticeble exception, sample FR-2001B displays a pronounced $\mathrm{Nb}$ positive anomaly and a $\mathrm{La} / \mathrm{Yb}_{N}$ ratio greater than unity (Fig. 4) typical of plume-like components (Corval, 2005). It should be noted that samples DB-I-34 and FR-2001B have similar $\mathrm{MgO}$ contents (Fig. 4) and as such differences in the $\mathrm{Nb}$ anomalies shown in the diagram cannot be attributed to evolutionary processes. In addition, such differences cannot be attributed to either within-dyke differentiation processes (e.g. simple contamination) or to the presence of unusual fractionting phases on the basis of field or petrographic evidence (Tavares et al., 2003). Finally, analytical errors are unlikely since sample FR-2001B also bears high Ta concentration as expected considering the $\mathrm{Nb}$-Ta geochemical affinitties. In conclusion, the $\mathrm{Nb}$ positive anomaly shown in the diagram of figure 4 can be considered as an evidence of the involvement of a fertile, plume-like component in the petrogenesis of the high- $\mathrm{TiO}_{2}$ basalts of the Serra do Mar Dyke Swarm.

Many authors have pointed to Tristan da Cunha as the plume involved with the geodynamic processes during the Gondwanaland breakup although the role of the plume in the rifting remains under debate (e.g. Gibson et al., 1995; Valente et al., 1999a; Mohriak et al., 2002; Marques and Ernesto, 2004).

The diagram in figure 4 presents the pattern of 


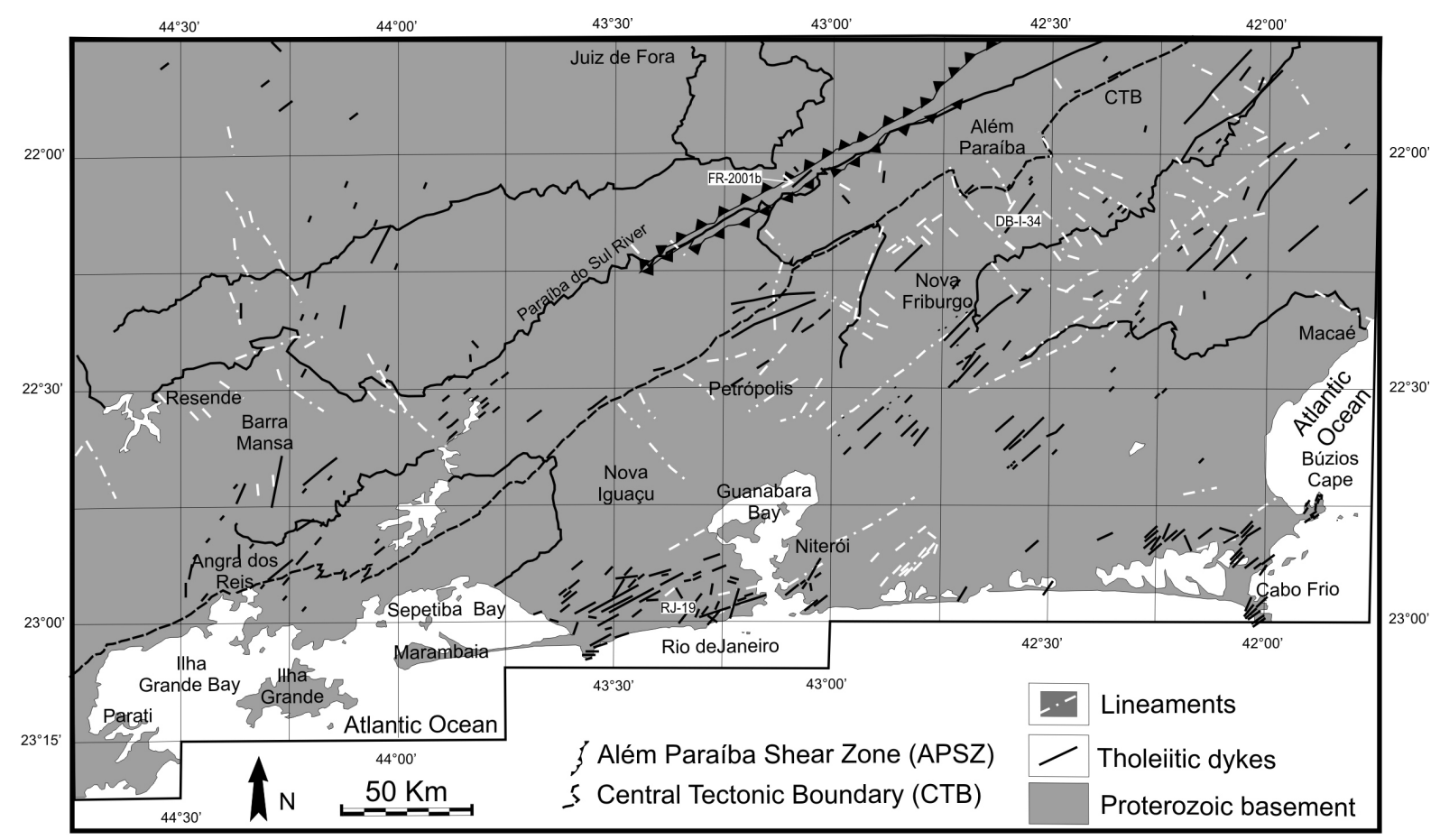

Figure 2 - Geological map of the Serra do Mar Dyke Swarm. The Além Paraiba Shear Zone (APSZ), the Central Tectonic Boundary (CTB) and location of samples FR2001b, DB-I-34 and RJ-19 are indicated. Regional structures of the Proterozoic basement are not shown as a matter of simplification. Modified from Valente et al., 2005 a.

a Tristan da Cunha basanite (TDC91; Le Roex et al., 1990) likely to represent a plume-related liquid. The $\mathrm{MgO}$ contents $(\mathrm{MgO}=4.77$ wt. $\%)$ of sample TDC91 is similar to that of the high- $\mathrm{TiO}_{2}$ basalt FR-2001B (4.75 wt.\%). Samples TDC91 and FR-2001B show similar patterns in the multielementar diagram with high LILE/HFSE ratios (TDC91: Ba/Y ${ }_{(\mathrm{N})}=14,2$; FR-2001B: $\left.\mathrm{Ba} / \mathrm{Y}_{(\mathrm{N})}=7,9\right)$. The greater enrichment factors of sample TDC91 are attributed to its alkaline composition likely to be related to lesser partial melting degrees of mantle sources when compared to the tholeitic composition of sample FR-2001B. Both samples TDC91 and FR2001B display the $\mathrm{Nb}$ positive anomaly typically associated with fertile mantle sources. In conclusion, the aforementioned features shown in the chondrite-normalized multielementar diagram (Fig. 4) in addition to the results of the Sr-Nd binary mixing modelling (Fig. 3) are indicative of a contribution of a Tristan da Cunha component in the petrogenesis of the high- $\mathrm{TiO}_{2}$ basalts of the Serra do Mar Dyke Swarm.

\section{GEODYNAMIC IMPLICATIONS OF THE} PETROGENETIC MODEL The geochemical data presented in the previous sections showed that the petrogenesis of the high- $\mathrm{TiO}_{2}$ basalts in the Serra do Mar Dyke Swarm is likely to have involved both the subcontinental lithospheric mantle and the Tristan da Cunha plume. Such petrogenetic model indicates that lithospheric and plume-like mantle components may have interacted during the Gondwanaland breakup.

Plume-like geochemical signatures (sample FR-2001B; $\mathrm{La} / \mathrm{Yb}_{N}=9.9$ and $\mathrm{La} / \mathrm{Nb}_{N}=0.3$ ) were found in a dyke intruded in the Proterozoic granulites of a major crustal structure, the so-called Além-Paraíba Shear Zone (APSZ; Campanha et al., 1985) along the northern portion of the Serra do Mar Dyke Swarm (Fig. 2).

Table 1 - Average Ti/Y, La/Yb and La/Nb ratios of the main low- and high-TiO suites of the Serra do Mar Dyke Swarm. Sources: Valente (1997); Corval (2005); Dutra (2006).

\begin{tabular}{|c|c|c|c|}
\hline Suite & $\mathrm{Ti} / \mathrm{Y}$ & $\mathrm{La} / \mathrm{Yb}$ & $\mathrm{La} / \mathrm{Nb}$ \\
\hline Low-TiO 2 (Serrana) & 290 & 6.3 & 1.7 \\
\hline Low-TiO 2 (Costa Azul) & 284 & 4.5 & 1.3 \\
\hline High- $\mathrm{TiO}_{2}$ (Suite 1; Urubici-like) & 603 & 14.2 & 1.6 \\
\hline High- $\mathrm{TiO}_{2}$ (suite 2) & 392 & 8.0 & 1.5 \\
\hline High- $\mathrm{TiO}_{2}$ (suite 3 ) & 883 & 29.2 & 2.8 \\
\hline
\end{tabular}




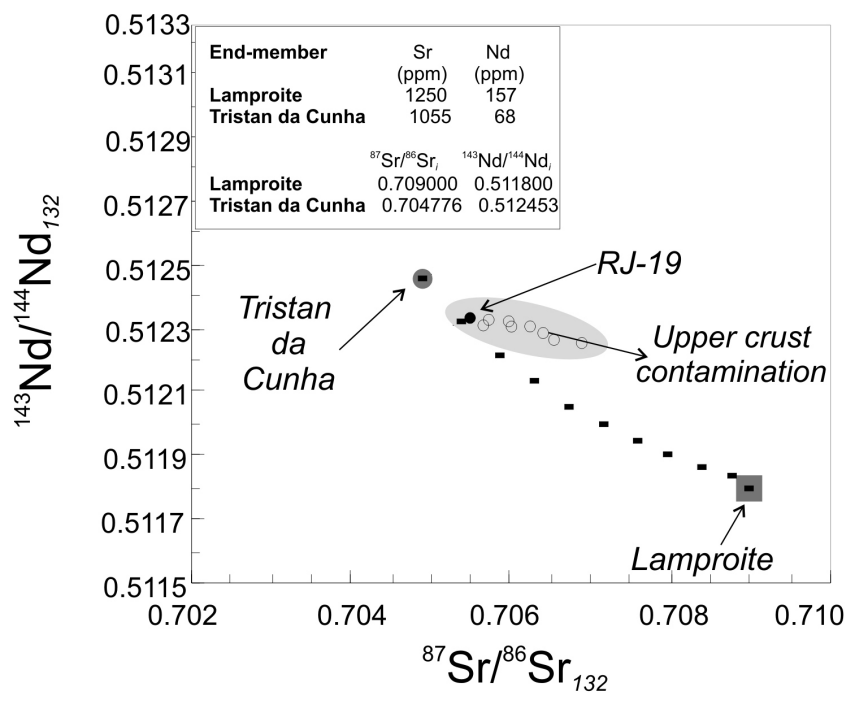

Figure 3 - Sr-Nd binary mixing modelling superimposed on the Sr-Nd isotopic trend of the high-TiO, basalts of the Serra do Mar Dyke Swarm with discernible lithospheric signatures. The mixing curve (tick marks) is shown with increments at $10 \%$ intervals; parameters being indicated. Tristan da Cunha data: ankaramitic basanites and basanites averages (Le Roex et al., 1990). Average lamproite is from Rock (1991). The Tristan da Cunha lavas were age-corrected (132 Ma) using the published Nd data assuming $\mathrm{Sm} / \mathrm{Nd}=0.2597$ (typical OIB, Sun \& McDonough, 1989). The high-TiO basalts trend (parental, less contaminated sample RJ-19, filled circle; contaminated dolerites, open circle) is shaded.

In this context, the following geodynamic scenarios may be envisaged for the Serra do Mar Dyke Swarm during the Gondwanaland breakup (Fig. 5).

One scenario implies the whole area of the Serra do Mar Dyke Swarm being submmited to the same amount of lithospheric thinning (ie., same $\beta$ factor) in a time a cold continental lithosphere with original differential thickness was placed over a thermal anomaly (plume) (Fig. 5a). The complex accretionary process of Gondwana in Proterozoic times (Heilbron et al., 2004; Valente et al., 2005b) may potentially have led to the amalgamation of terranes with variable lithospheric thickness. As much as the anomalously thinned continental lithosphere allowed sublithospheric-related basalts (i.e., $\mathrm{La} / \mathrm{Nb}<1$ ) would spread over the entire dyke swarm (Fig. 5b). In this case, the occurence of basalts showing the contribution of sublithospheric components would not have to be coincident with major crustal weakness zones such as the APSZ. Another scenario implies the presence of a cold continental lithosphere over a thermal anomaly with an overall original uniform thickness (Fig. 5c) but submmited to distinctive $\beta$ factors that would be greater when coincident with major crustal structures such as the APSZ (Fig. 5d). Such crustal structure could have acted as weakness zones reactivated as a result of the Gondwanaland breakup and might have released stress onto the adjoining subcontinental lithospheric mantle leading to greater lithospheric thinning on a local scale. Structural studies on the rift basins along the Eastern Rift System of Brazil have stressed the role of reactivation processes during basin formation related to the Gondwanaland breakup (e.g., Chang et al., 1992; Mohriak et al., 2002). The widespread occurence of subcontinental lithospheric mantle-derived melts within the Serra do Mar Dyke Swarm indicates that such crustal reactivation and its possible related stress release onto the subcontinental lithospheric mantle was not great enough to result in amounts of lithospheric thinning capable of promoting adiabitic decompression and melting of the subjacent mantle plume on a large scale. It should be noted that the APSZ is located about $20 \mathrm{Km}$ north to the Central Tectonic Boundary, a main suture bounding the so-called Eastern and Western terranes (Fig. 6) within the Ribeira Orogen (Heilbron et al., 2004).

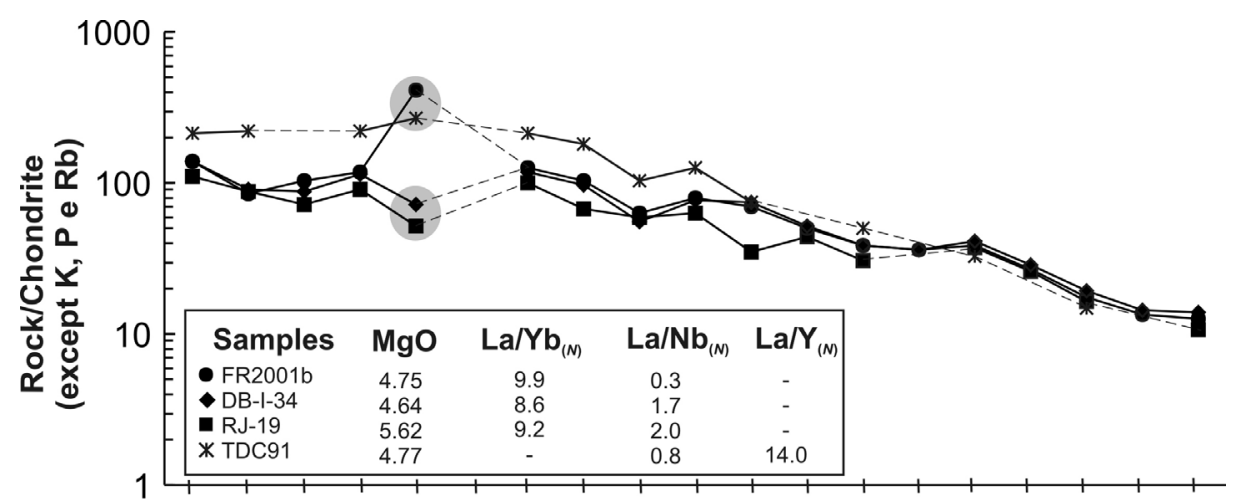

Ba Rb Th K Nb Ta La Ce Sr Nd P Sm Zr Hf Ti Tb Y Tm Yb

Figure 4 - Chondrite-normalized multielementar diagram (Thompson, 1982) for selected samples of the high-TiO, suite of the Serra do Mar Dyke Swarm. Sample TDC91 (Tristan da Cunha basanite; Le Roex et al., 1990) is also shown in the diagram as an example for a plume-related liquid. The Nb anomalies are shown in light-grey areas. $\mathrm{MgO}$ contents in wt.\%. 


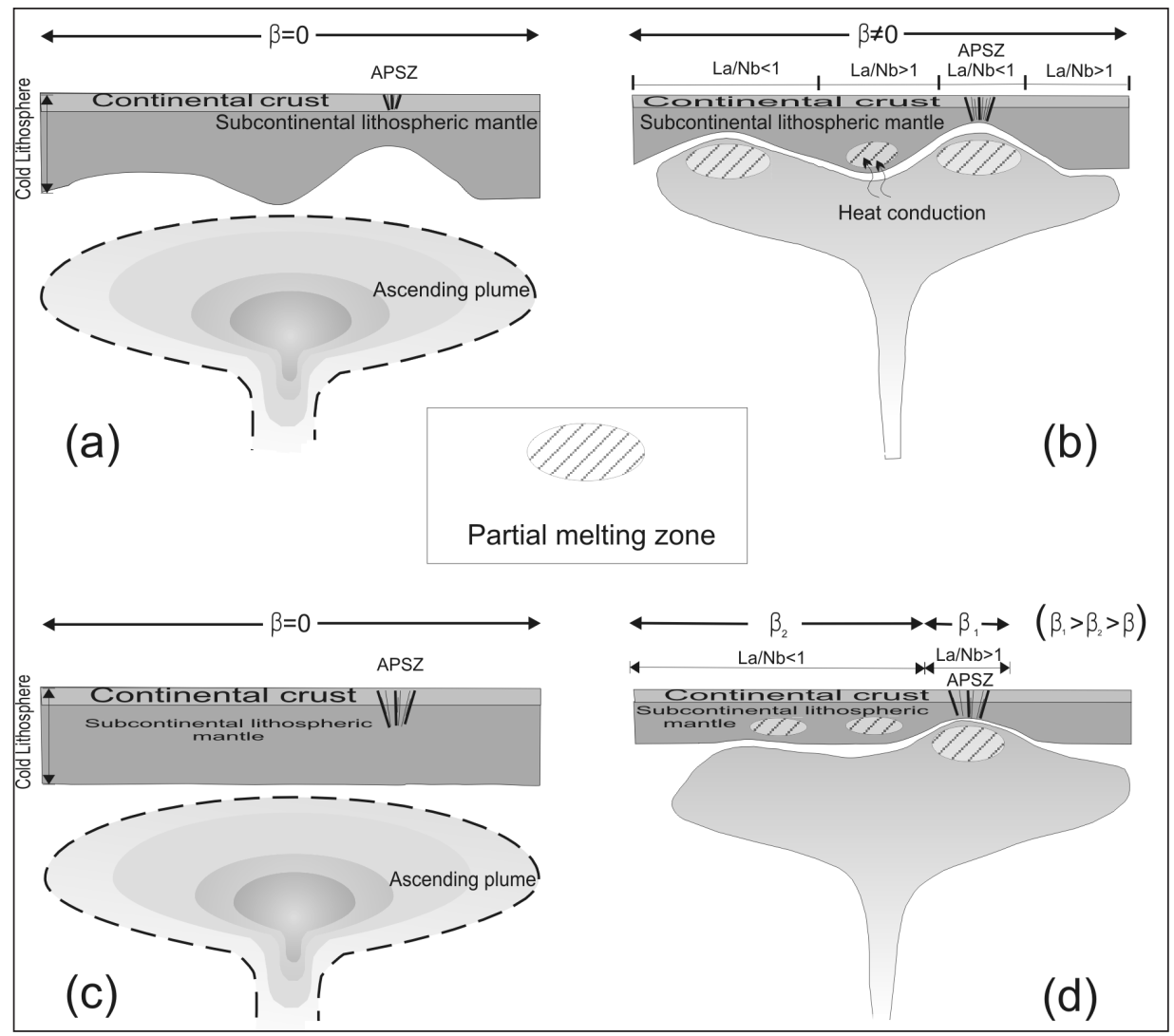

Figure 5 - Envisaged scenarios for the geodynamics of the Gondwanaland breakup and its related magmatism within the Serra do Mar Dyke Swarm. (a) and (b) respectively represent the unstreched and streched continental lithosphere of variable thickness and impinging plume in the Serra do Mar Dyke Swarm latitudes under uniform lithospheric thinning (ie., $\beta$ factors); (c) and (d) represent the unstreched and streched continental lithosphere of same thickness and impinging plume in the Serra do Mar Dyke Swarm latitudes under different $\beta$ factors. Expected partial melting zones and La/Nb ratios are indicated. APSZ is the Além Paraíba Shear Zone. Not in scale.

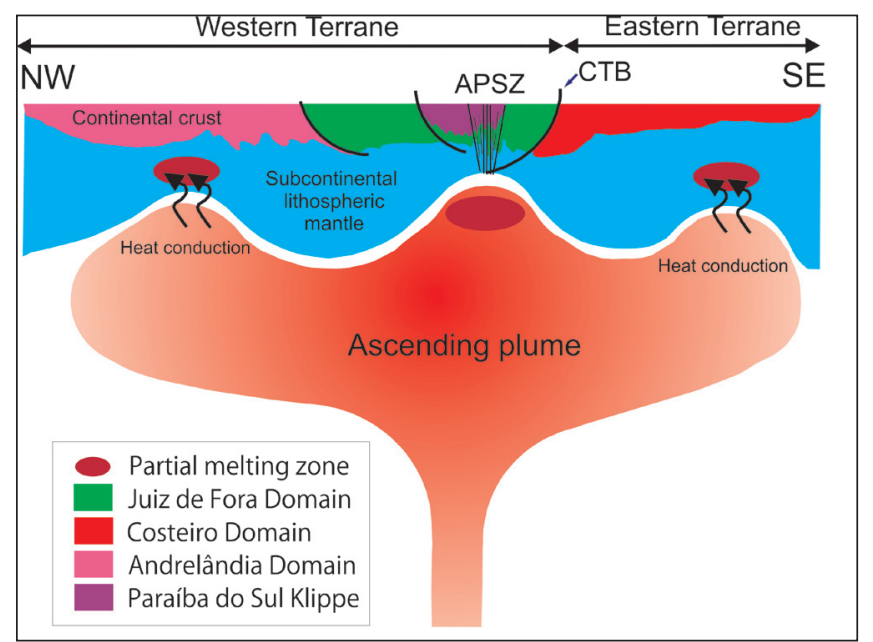

Figure 6 - Diagram representing the preferred geodynamic scenario for plume-lithosphere interactions during Gondwanaland breakup and the Serra do Mar related magmatism. Tectonic terranes, boundaries and domains after Heilbron et al. (2004). Not in scale.

CTB: Central Tectonic Boundary limiting the Oriental and Occidental Terranes. APSZ: Além Paraíba Shear Zone.
In this case, on the basis of those evidences we prefer a model that places crustal reactivation zones nearby major tectonic terrane boundaries, the latter being potential loci of originally anomalously thinned lithosphere so that an ascending plume would be able to melt by adiabatic decompression. In conclusion, the Tristan da Cunha plume may have melted locally in places where the Gondwanaland lithosphere had undergone greater thinning due to the reactivation of crustal weakness zones nearby major terrane boundaries amalgamated in Proterozoic times resulting in the generation of restricted volumes of plume-derived tholeiitic basalts. In contrast, on a regional scale the thick Gondwanaland lithosphere may have largely prevented plume melting even in places where crustal reactivation occurred and in these cases heat may have been conducted to and largely melted the heterogeneous, overlying subcontinental lithospheric mantle.

Acknowledgments Artur Corval and Thiago Dutra hold a CAPES schoolarship in the FGEL-UERJ. Beatriz Paschoal Duarte and Sérgio Valente hold a CNPq research schoolarship. 


\section{References}

Almeida F.F.M., Hasui Y., Brito Neves B.B. 1976. The upper precambrian of South America. Bol. Inst. Geoc. USP., 7:45-80.

Cainelli C. \& Mohriak W.U. 1999. Some remarks on the evolution of sedimentary basins along the Eastern Brazilian Continental Margin. Episodes, 22:206-216.

Campanha G.A.C., Riccomini C., Melo M.S., Hasui Y., Almeida F.F.M., Dehira L.K. 1985. Análise do padrão de fraturamento Mesozóico-Cenozóico de bacias tafrogênicas continentais do Sudeste do Brasil. In: SBG, Simp. Reg. Geol.,5, Atas, p. 337-350.

Chang H.K., Kowsman R.O., Figueiredo A.M., Bender A.A. 1992. Tectonics and stratigraphy of the East Brazil Rift System - An overview: Tectonophysics, 213:97-138.

Comin-Chiaramonti P., Gomes C.B., Piccirillo E.M., Rivalenti G. 1983. High-TiO 2 basaltic dykes in the coastline of São Paulo and Rio de Janeiro states (Brazil). Neus. Jahr. Miner. Abh., 146:133-150.

Corval A. 2005. Petrogênese das suítes basálticas toleiticas do Enxame de Diques da Serra do Mar nos setores central e norte do estado do Rio de Janeiro. Rio de Janeiro, Dissertação de Mestrado, Faculdade de Geologia, Universidade do Estado do Rio de Janeiro, 92 p.

Dutra T. 2006. Petrogênese dos basaltos de baixo-TiO do Enxame de Diques da Serra do Mar na Região dos Lagos, RJ. Rio de Janeiro, Dissertação de Mestrado, Faculdade de Geologia, Universidade do Estado do Rio de Janeiro, 111 p.

Fodor R.V., McKee E.H., Asmus H.E. 1983/84. K-Ar ages and the opening of the South Atlantic ocean: basaltic rock from the Brazilian margin. Marine Geology, 54:M1-M8.

Fodor R.V. \& Vetter S.K. 1984. Rift-zone magmatism: petrology of basaltic rocks transitional from CFB to MORB, Southeastern Brazil margin. Contributions to Mineralogy and Petrology, 88:307-321.

Fodor R.V.; Corwin C. \& Rosemberg A. 1985. Petrology of Serra Geral (Paraná) continental flood basalts, Southern Brazil: crustal contamination, source material, and South Atlantic magmatism. Contributions to Mineralogy and Petrology, 91:54-65.

Garda G.M. 1995. Os diques básicos e ultrabásicos da região costeira entre as cidades de São Sebastião e Ubatuba, Estado de São Paulo. São Paulo, Tese de doutoramento, Instituto de Geociências, Universidade de São Paulo, 156 p.

Gibson S.A., Thompson R.N., Dickin A.P., Leonardos O.H. 1995. High-Ti and low-Ti mafic potassic magmas: Key to plume-lithosphere interactions and continental floodbasalt genesis. Earth and Planetary Science Letters, 136:149-165.

Guedes E., Heilbron M., Valente, S.C.1999. Litogeoquímica e petrografia dos diques máficos da região entre Pedra Selada e Barra do Piraí, RJ, SE do Brasil. In: SBG-BA, Congresso de Geoquímica de Países de Língua Portuguesa, 5, e Congresso Brasileiro de Geoquímica, 7, Boletim de Resumos Expandidos, p. 516.

Guedes E., Heilbron M., Vasconcelos P.M., Valeriano C.M., Almeida J.C.H., Teixeira W., Thomaz Filho A. 2005.
$\mathrm{K}-\mathrm{Ar}$ and ${ }^{40} \mathrm{Ar} /{ }^{39} \mathrm{Ar}$ ages of dykes emplaced in the onshore basement of the Santos Basin, Resende area, SE Brazil: implications for the south Atlantic opening and Tertiary reactivation. Journal of South American Earth Sciences, 18:371-382.

Hawkesworth C.J., Gallagher K., Kelley S., Mantovani M., Peate D.W., Regelous M., Rogers N.W.1992. Paraná magmatism and the opening of the South Atlantic. In: B.C Storey., T. Alabaster, R.J. Pankhurst (eds.) Magmatism and the causes of continental break-up. Special Publication of the Geological Society of London, 68, p. 221-240.

Heilbron M., Mohriak W., Valeriano C.M. Milani E., Almeida J.C.H., Tupinambá M. 2000. From collision to extension: the roots of the southeastern continental margin of Brazil. In: W.U. Mohriak, \& M. Talwani (eds.) Atlantic rifts and continental margins. American Geophysical Union, 115, Geoph. Monogr. Ser., p. 1-32.

Heilbron M., Pedrosa-Soares A.C., Campos Neto M.C., Silva L.C., Trow R.A.J., Janasi V.A. 2004. Província Mantiqueira. In: V. Mantesso-Neto, A.Bartorelli, C.D.R. Carneiro, B.B. Brito-Neves (eds.) Livro Geologia do Continente Sul-Americano: Evolução da obra de Fernando Flávio Marques de Almeida. São Paulo, SBG-SP, 1a ed., Editora Beca, p. 203-234.

LeRoex A.P., Cliff R.A., Adair B.J.I. 1990. Tristan da Cunha, South Atlantic: geochemistry and petrogenesis of a basanite-phonolite lava series. Journal of Petrology, 31:779812.

Lobo J.T., Valente S.C., Thomaz Filho A., Szatmari P.1999. Diabásios da Serra do Mar e basaltos da Bacia de Campos - comparação dos processos de AFC através de modelamento geoquímico quantitativo. In: SBG, Simp. Geol. Sudeste, 5, Boletim de Resumos Expandidos, p. 56.

Marques L.S., Dupré B., Piccirillo E.M.1999. Mantle source compositions of the Paraná Magmatic Province (southern Brazil): evidence from trace element and $\mathrm{Sr}-\mathrm{Nd}-\mathrm{Pb}$ isotope geochemistry. Journal of Geodynamics, 28:439458.

Marques L. S., Piccirillo E. M., Bellieni G., Figueiredo A. M. G., Min A. 2003. Caracterização geoquímica dos diques mesozóicos de natureza toleítica da costa sudeste do Brasil. In: SBGq, Congresso Brasileiro de Geoquímica, 9, Resumos Expandidos, p. 652-654.

Marques L.S. \& Ernesto M. 2004. O magmatismo Toleítico da Bacia do Paraná. In: V. Mantesso-Neto, A. Bartorelli, C.D.R. Carneiro, B.B. Brito-Neves (eds.) Livro Geologia do Continente Sul-Americano: Evolução da obra de Fernando Flávio Marques de Almeida. São Paulo, SBG-SP, 1a ed., Editora Beca, p. 245-263.

Milani E.J. \& Thomaz Filho A. 2000. Sedimentary basins of South America. In: U.G. Cordani, E.J. Milani, A.Thomaz Filho, D.A.Campos (eds.) Tectonic evolution of South America. Rio de Janeiro, SBG-RJ, UERJ, p. 389-452.

Mizusaki A.M.P., Petrini R., Bellieni G., Comin-Chiaramonti P., Dias J., DeMin A., Piccirillo E.M. 1992. Basalt magmatism along the passive continental margin of SE Brazil (Campos basin). Contributions to Mineralogy and Petro- 
$\log y$, 111:143-160.

Mizusaki A.M.P. \& Thomaz Filho A. 2004. O Magmatismo pós-Paleozóico no Brasil. In: V. Mantesso-Neto, A.Bartorelli, C.D.R. Carneiro, B.B. Brito-Neves (eds.) Livro Geologia do Continente Sul-Americano: Evolução da obra de Fernando Flávio Marques de Almeida. SBGSP, 1a ed., Editora Beca, p. 281-291.

Mohriak W. U., Rosendahl B.R., Turner J. P., Valente, S. C. 2002. Crustal architecture of South Atlantic volcanic margins. In: M.A. Menzies \& C. Ebinger (eds.) Volcanic rifted margins. Geological Society of America, 362, Ed. Boulder, p. 159-202.

Monteiro H.L.J. \& Valente S.C. 2003. Estudo Petrológico comparativo das suítes de baixo-TiO, do Enxame de Diques da Serra do Mar. In: UFRuralRJ, Jornada de Iniciação Científica, volume único, Anais, p. 54-55.

Peate D.W., Hawkesworth C.J., Mantovani M.S.M. 1992. Chemical stratigraphy of the Paraná lavas (South America): classification of magma types and their spatial distribution. Bulletin of Volcanology, 55:119-139.

Peate D.W. 1997. The Parana-Etendeka province. In: J.J.Mahoney \& M.F. Coffin (eds.) Large igneous provinces: continental, oceanic and planetary flood volcanism. American Geophysical Union, 100, Geophysical Monograph Series, p. 217-245.

Piccirillo E.M. \& Melfi A.J. (Eds.) 1988. The Mesozoic flood volcanism of the Paraná basin: petrogenetic and geophysical aspects. São Paulo, IAG-USP, 600 p.

Piccirillo E.M., Bellieni G., Cavazzini G., Comin-Chiaramonti P., Petrini R., Melfi A.J., Pinesi J.P.P., Zantadeschi P., DeMin A. 1990. Lower Cretaceous tholeiitic dyke swarms from the Ponta Grossa (southeast Brazil): Petrology, Sr-Nd isotopes and genetic relationships with the Paraná flood volcanics. Chemical Geology, 89:19-48.

Raposo M.I.B., Ernesto M., Renne P.R.1998. Paleomagnetism and ${ }^{40} \mathrm{Ar} /{ }^{39} \mathrm{Ar}$ dating of the Early Cretaceous Florianópolis Dyke Swarm (Santa Catarina Island), Southern Brazil. Physics of the Earth and Planetary Interiors, 108:275-290.

Regelous M. 1993. Geochemistry of dolerites from the Paraná flood basalt province, southern Brazil. $\mathrm{PhD}$ thesis, Open University, $200 \mathrm{p}$.

Rock N.M.S. (Eds.) 1991. Lamprophyres. London, Blackie \& Son, 284 p.

Schmitt R.S., Trouw R.A.J., Van Schmus W.R., Pimentel M.M. 2004. Late amalgamation in the central part of West Gondwana: New geochronological data and the characterization of a Cambrian collisional orogeny in the Ribeira Belt (SE Brazil). Precambrian Research, 133:2961.

Sun S.S. \& McDonough W.F. 1989. Chemical and isotopic systematics of oceanic basalts: implications for mantle composition and processes. In: A.D. Saunders \& M.J. Norry (eds.) Magmatism in the ocean basins. Special Publication of the Geological Society of London, v. 42, p. 313-345.

Tavares E., Valente S.C., Corval A. 2003. Processos subsolidus relacionados às fases opacas dos diabásios do Enxame de Diques da Serra do Mar. In: SBG-RJ, $8^{\circ}$ Simp. Geol. Sudeste, volume único, Boletim de Resumos, p. 69.
Tetzner W., Camillo E.J.R., Almeida J.C.H. 2001. Tectônica Mesozóica e emplacement dos diques básicos do Cabo de Búzios, RJ. In: SBG-RJ, Simp. Geol. Sudeste, 7, Boletim de Resumos, p. 91-92.

Thomaz Filho A., Misuzaki A.M.P., Milani E.J., Cesero P. 2000. Rifting and magmatism associated with the South America and Africa breakup. Revista Brasileira de Geociências, 30:17-19.

Thompson R.N. 1982. Magmatism of the British Tertiary volcanic province. Scot. Geol., 18:49-107.

Turner S., Regelous M., Kelley S., Hawkesworth C., Mantovani M. 1994. Magmatism and continental break-up in the South Atlantic: High precision ${ }^{40} \mathrm{Ar} /{ }^{39} \mathrm{Ar}$ geochronology. Earth and Planetary Science Letters, 121:333-348.

Valente S.C. 1997. Geochemical and isotopic constraints on the petrogenesis of the Cretaceous dykes of Rio de Janeiro, Brazil. Belfast, PhD. Thesis, The Queen's University of Belfast, $366 \mathrm{p}$.

Valente S.C., Ellam R.L., Meighan I.G., Fallick A.E. 1998a. Geoquímica isotópica, modelo geodinâmico e petrogênese dos diabásios do cretácio Inferior no Enxame de Diques Máficos da Serra do Mar (EDSM) na área de do Rio de Janeiro, RJ. In: SBG -MG, Congresso Brasileiro de Geologia, 40, Boletim de Resumos, p. 471.

Valente S.C., Ellam R.L., Meighan I.G., Fallick A.E. 1998b. Petrogênese dos diques alcalinos do Rio de Janeiro e a natureza dos processos mantélicos no Cretácio Superior sob a Serra do Mar, RJ. In: SBG -MG, Congresso Brasileiro de Geologia, 40, Boletim de Resumos, p. 486.

Valente S.C., Ellam R.L., Meighan I.G., Fallick A.E. 1999a. The Serra do Mar and Ponta Grossa Dyke Swarms: Dynamic Melting and Geodynamic Models for the Early Cretaceous in Southeast Brazil. In: SBG -MG, Simpósio Nacional de Estudos Tectônicos, 7, e Simpósio Internacional de Tectônica, 1, Boletim de Resumos, p. 102-103.

Valente S.C., Ellam R.L., Meighan I.G., Fallick A.E. 1999b. The evolution of the Early Cretaceous tholeiitic dykes of Rio de Janeiro by AFC under high $\mathrm{fO}_{2}$ conditions: Major and trace element, Sr-Nd-O data and quantitative modelling. In: SBG -PR, Simpósio Sul Brasileiro de Geologia, 7, e Encontro de Geologia do Mercosul, 2, Boletim de Resumos, p. 94.

Valente S.C., Duarte B.P., Heilbron M., Almeida J.C.H., Valladares C.S., Guedes E., Tetzner W., Lobo J., Corval A., Dutra T., Soares L.H., Souza F.M., Vinha J., Famelli N. 2005a. Mapa do Enxame de Diques da Serra do Mar. In: SBG-RJ, Simpósio de Vulcanismo e Ambientes Associados, 3, Anais, p. 207-211.

Valente S.C., Duarte B.P., Heilbron M., Corval A., Valladares C., Almeida J.C.H., Guedes E. 2005b. Provincialidade geoquímica do Enxame de diques da Serra do Mar e domínios tectônicos do Orógeno Ribeira: o Cretáceo como uma janela para o Proterozóico. In: SBG-PR, Simpósio Nacional de Estudos Tectônicos, 10, e International Symposium on Tectonics, 7, Boletim de Resumos $\mathrm{p}$. 283-285.

Manuscrito AE-050/2006

Recebido em 24 de outubro 2006 Aceito em 30 de maio de 2007 